\section{СТАН ТА ОСОБЛИВОСТІ РОЗВИТКУ ПЛОДОВООЧІВНИЦТВА У ВІННИЦЬКІЙ ОБЛАСТІ ${ }^{\odot}$}

\author{
САМБОРСЬКА О.Ю., \\ кандидат економічних наук, \\ доцент кафедри адміністративного \\ менеджменту \\ та альтернативних джерел енергї, \\ Вінницький національний \\ аграрний університет
}

У статті досліджено сучасний стан та особливості розвитку садівництва у Віннищькій області, щзо передують особливі природно-кліматичні, економічні умови. Враховано чинники зовнішнього та внутрішнього середовища на перспективи розвитку садівництва у області. Проведений аналіз підприємств Віннищької області, які складають основу вирощування та переробки продукції плодоовочівництва. Підприємства Вінницької області, щчо досліджувалися, розробили маркетингову стратегію виходу на нові міжнародні ринки збуту продукиії, вдосконалили рекламу та якість продукиії, умови сортування та транспортування. Собівартість продукиї зібраної з використанням ручної прачі в рази більща за вартість зібраної та сортованої продукиії на підприємствах з механізованою технікою. Для повної оиінки обсягів продукиї садівництва у області досліджено врожайність та валовий збір за окремі роки. Зростання обсягів врожаю плодово-ягідної продукції сприяє розвитку переробних підприємств Вінницької області та виходу на нові ринки збуту з готовою продукиією у свіжому або замороженому вигляді. Представлені типові овочеві товари, які експортуються до краӥн Європейського Союзу.

Наведені приклади споживання основних видів продукиї в розрахунку на одну особу за медичними нормами визначеними Всесвітньою організаиією охорони здоров'я. Прослідковується поступове зменшення споживання овочів, фруктів та ягід на одну особу, неплатоспроможність споживачів, важкі умови роботи, відсутність державної підтримки призвели до таких результатів.

На сьогодні розвиток плодоовочівництва сприяе економічному зростанню аграрного сектору не тільки аналізованої області, а України в иілому. Вирощення якісної продукиії садівництва за доступну ціну для всіх категорій населення дозволяє збільшити обсяги споживання такої продукиії, щзо в свою чергу покращує самопочуття та стан здоров'я населення. Проведені дослідження, допомагають розробиі комплексної програми продовольчої безпеки області та краӥни для забезпечення повночінного харчування населення з врахуванням медичних норм.

Ключові слова: плодоовочівництво, сільське господарство, здорове харчування, норми, розвиток, збут продукції.

Табл.: 6. Рис.: 2. Літ.: 13.

\title{
STATE AND FEATURES OF FRUIT GROWING DEVELOPMENT IN VINNYTSIA REGION
}

\section{SAMBORSKA Oksana, \\ PhD, associate professor Department of Administrative management and alternative energy sources \\ Vinnytsia National Agrarian University \\ (Vinnytsia)}

The article investigates the current state and peculiarities of horticulture development in Vinnytsia region, which are preceded by special natural-climatic and economic conditions. The factors of external and internal environment on the prospects of horticulture development in the region are considered. The analysis of the enterprises of Vinnytsia region, which form the basis of growing and processing of fruit and vegetable products. The investigated enterprises of Vinnytsia region have developed a marketing strategy for entering new international markets of products, improved advertising and product quality, sorting and transportation conditions. The cost of production collected using manual labor is several times higher than the cost of collected and sorted products at the enterprises with mechanized machinery. In order to fully evaluate the volume of horticultural products in the region, the yield and gross harvest for individual years were investigated. The 
increase in the volume of fruit and berry production contributes to the development of processing enterprises in Vinnytsia region and to entering new markets with finished products in fresh or frozen form. Typical vegetable products exported to European Union countries are presented.

For an example of consumption of basic products per person according to the medical standards defined by the World Health Organization are given. There is a gradual decrease in consumption of vegetables, fruits and berries per person, insolvency of consumers, difficult working conditions, lack of state support have led to such results.

Today, the development of fruit and vegetable production contributes to the economic growth of the agricultural sector not only in the analyzed region, but in Ukraine as a whole. Growing quality horticultural products at an affordable price for all categories of the population allows to increase the consumption of such products, which in turn improves the well-being and health of the population. The conducted researches help to develop a comprehensive program of food security of the region and the country for providing full nutrition of the population in accordance with medical norms. products.

Key words: fruit and vegetable growing, agriculture, healthy nutrition, norms, development, sale of

Table. 6. Fig 2. Lit. 13.

\title{
СОСТОЯНИЕ И ПЕРСПЕКТИВЫ РАЗВИТИЯ ПЛОДОВОЧИВНИЦТВА В ВИННИЦКОЙ ОБЛАСТИ
}

\author{
САМБОРСКАЯ О.Ю., \\ кандидат экономических наук, \\ доцент кафедры административного менеджмента \\ и альтернативных источников энергии \\ Винницкий национальный аграрный университет
}

В статье исследовано современное состояние и особенности развития садоводства в Винницкой области, предшествующих особые природно-климатические, экономические условия. здоровья населения. Проведенные исследования, помогают разработке комплексной программы продовольственной безопасности области и страны для обеспечения полноценного питания населения с учетом медицинских норм.

Ключевые слова: плодовое хозяйство, сельское хозяйство, здоровое питание, нормы, развитие, сбыт продукции.

Табл.: 6. Рис.: 2. Лит.: 13.

Постановка проблеми. Розвиток товарного виробництва плодів і ягід характеризується певними регіональними відмінностями: грунтовими, кліматичними та економічними умовами, що склалися в окремих районах України. Ці відмінності позначаються на формуванні виробничого 
потенціалу галузі, зокрема, породо-сортової структури насаджень, а також їх продуктивності, обсягах виробництва і споживання плодів і ягід на душу населення, ефективності виробництва продукції, іiі попиту і пропозиції на внутрішньому й зовнішніх ринках тощо. Тому питання підвищення ефективності функціонування промислового садівництва повинні вирішуватися з урахуванням зональних особливостей його ведення. Вінницька область є провідним центром розвитку та вирощування плодів та ягід в Україні. Більша частка у структурі сільського господарства у вирощуванні продукції садівництва припадає на сімейні домогосподарства населення. Такий збір продукції переважно проводиться з використанням ручної праці, тому собівартість такої продукції зростає в рази порівняно з ринковими цінами. Різке зменшення обсягів виробництва і споживання плодової продукції, скорочення плодоносних площ багаторічних насаджень, відсутність необхідної фінансової підтримки з боку держави призведе до збитковості виробництва продукції цієї галузі в більшості сільськогосподарських підприємств вінницького регіону.

Ведення такого господарства тягне чимало проблем: швидке псування продукції, важкі умови транспортування на великі відстані, сортування продукції за розмірами, фасування у тару, маркування та інше.

Аналіз останніх досліджень і публікацій. Дослідженням стану та розвитком сільського господарства займалися науковців як: Азізов С.П. [1], Саблук П.Т. [1], Канінський П.К. [1], Косовець Г.М. [6], Шевчук Г.В. [9].

С.П. Азізов [1] підкреслює, що проблема виходу економіки України з кризового стану вбачає пошук шляхів підвищення ефективності виробництва продукції, через аграрний сектор. При цьому він вказує на те, що підвищення ефективності аграрного виробництва пов'язане з оцінкою та врахуванням чинників зовнішнього та внутрішнього ринкового середовища, які визначають ресурсний потенціал вітчизняної аграрної сфери економіки в умовах глобалізації.

Г.В. Шевчук [9] в своїй роботі здійснює дослідження факторів, що впливають на ефективність організаційно-економічного механізму удосконалення плодоовочевої галузі. Автор наголошує на тому, що організаційно-економічний механізм функціонування підприємств плодоовочевої галузі, що містить підсистеми забезпечення, цільову підсистему, функціональну підсистему забезпечення виробничих процесів, сприятиме вирішенню ряду економічних питань у розвитку регіонів, загальному підвищенню ефективності аграрного сектору. Він допоможе поєднати державне регулювання та внутрішньогосподарське управління діяльністю сільськогосподарських товаровиробників.

Здійснені дослідження в сфері поглиблення розуміння та підвищення ефективності діяльності вітчизняних підприємств, що вирощують плодоовочеву продукцію підкреслюють важливий внесок такого сегменту в розвиток аграрного сектору економіки України.

Формулювання цілей статті. Метою статті $є$ дослідження стану та особливостей підвищення економічної ефективності вирощування плодів, ягід та овочів на прикладі Вінницької області.

Виклад основного матеріалу дослідження. Всесвітня організація охорони здоров'я (ВОО3) вважає, що раціон здорового харчування повинен включати фрукти та овочі: яблука, моркву, капусту, помідори, гострий перець, броколі, цибулю, чорницю і т. п. Всі ці продукти мають унікальне поєднання активних елементів, які зміцнюють імунну систему, знищують ракові клітини, підтримують роботу серця, клітин головного мозку і судин, позитивно впливають на психологічний стан i настрій людини [11]. Обов'язково розробка комплексної програми продовольчого забезпечення держави повинна бути пов'язана 3 програмами здорового харчування та аграрного виробництва. Споживання овочів та фруктів за рік на одну особу розглянемо у табл. 1.

Споживання фруктів та овочів на одну особу на рік, (кг)

\begin{tabular}{|c|c|c|c|c|c|c|c|}
\hline Назва & 2012 & 2013 & 2014 & 2015 & 2016 & 2017 & 2018 \\
\hline Картопля & 140 & 135 & 141 & 138 & 140 & 140 & 146 \\
\hline $\begin{array}{l}\text { Овочі та та баштанні } \\
\text { продовольчі культури }\end{array}$ & 163 & 163 & 163 & 161 & 164 & 161 & 163 \\
\hline Плоди, ягоди та виноград & 53 & 56 & 52 & 51 & 50 & 54 & 56 \\
\hline
\end{tabular}

Джерело: складено за даними Державної служби статистики України

Розрахунки норм споживання плодів та овочів не однакові і на фізіологічні (мінімальні) i медичні (оптимальні) [12]. Крім того, медичні норми, які використовуються на даний час, коливаються за різними джерелами (табл.2.) 


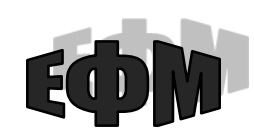

http://efm.vsau.org/

Таблиия 2.

Норми споживання овочів та фруктів на одну особу на рік, (кг)

\begin{tabular}{|l|c|c|c|c|c|}
\hline \multicolumn{1}{|c|}{ Продукти } & $\begin{array}{c}\text { Раціональна } \\
\text { норма } \\
\text { (розрахунки } \\
\text { МО3 України) }\end{array}$ & $\begin{array}{c}\text { Фактичне } \\
\text { споживання у } \\
\mathbf{2 0 1 6} \mathbf{p .}\end{array}$ & $\begin{array}{c}\text { Індикатор } \\
\text { достатності } \\
\text { споживання }\end{array}$ & $\begin{array}{c}\text { Фактичне } \\
\text { споживання у } \\
\mathbf{2 0 1 5} \mathbf{p .}\end{array}$ & $\begin{array}{c}\text { споживання } \\
\mathbf{2 0 1 8} \mathbf{p .}\end{array}$ \\
\hline Овочі і баштанні & 161 & 163,7 & 1,02 & 160,8 & 102 \\
\hline $\begin{array}{l}\text { Плоди, ягоди та } \\
\text { виноград }\end{array}$ & 90 & 49,7 & 0,55 & 50,9 & 44,4 \\
\hline Картопля & 124 & 139,8 & 1,13 & 137,5 & 138 \\
\hline
\end{tabular}

Джерело: складено за даними Державної служби статистики Украӥни [3]

За даними Міністерства охорони здоров'я, встановлена норма споживання овочів та фруктів (свіжі, перероблені, заморожені) - 350 грамів овочів та 330 грамів фруктів на день. Фактичне споживання цих продуктів ми можемо побачити в таблиці 2. [13].

Більш детально розглянемо врожайність плодів, овочів та фруктів у Вінницькій області у табл. 3.

Таблицяя 3.

Урожайність плодів, овочів, фруктів у Вінницькій області 2012-2016 рр.

\begin{tabular}{|c|c|c|c|c|c|c|c|c|}
\hline \multirow{3}{*}{ Роки } & \multicolumn{4}{|c|}{ Валовий збір, тис. грн. } & \multicolumn{4}{|c|}{ Урожайність, ц/га площі збору } \\
\hline & \multicolumn{2}{|c|}{ Плоди, ягоди } & \multicolumn{2}{|c|}{ ОВочі } & \multicolumn{2}{|c|}{ Плоди, ягоди } & \multicolumn{2}{|c|}{ Овочі } \\
\hline & Вінницька область & \% до 2017 p. & Вінницька область & \% до 2017 p. & Вінницька область & \% до 2016 p. & Вінницька область & \% до $2016 \mathrm{p}$. \\
\hline 2012 & 248 & 21,77 & 388 & 38,17 & 112,9 & 12,31 & 198,0 & 16,06 \\
\hline 2013 & 252 & 19,84 & 366 & 27,60 & 109,7 & 15,59 & 178,6 & 28,67 \\
\hline 2014 & 275 & 9,82 & 482 & $-3,11$ & 119,2 & 6,38 & 231,6 & $-0,78$ \\
\hline 2015 & 243 & 24,28 & 457 & 2,19 & 101,9 & 24,44 & 221,3 & 3,84 \\
\hline 2016 & 292 & 3,43 & 460 & 1,52 & 121,5 & 4,36 & 221,2 & 3,89 \\
\hline 2017 & 302 & - & 467 & - & 126,8 & - & 229,8 & - \\
\hline 2018 & 455 & & 102 & & 233 & & 234 & \\
\hline
\end{tabular}

Джерело: за даними Державної служби статистики [3]

За даними табл. 3 у 2017-2018 pр. у Вінницькій області врожайність фруктів, овочів збільшилася порівняно з попередніми роками, це свідчить про розвиток плодоовочівництва в області.

Варто відзначити, що у Вінницькій області станом на 2016 рік функціонують 46 фруктосховищ ємністю 55 тис. т. У 2015 році було введено в експлуатацію три фруктових сховища загальною місткістю 8,1 тис. т. (Жмеринський та Іллінецький райони). Щодо овочесховищ, то в регіоні розміщено 38 таких одиниць загальною потужністю 7,2 тис. т. Загалом за період 2012-2016 pp. у Вінницькій області було реалізовано інвестиційних проектів загальною потужністю 8,1 тис. т. на суму 2,2 млн грн [2].

32016 по 2018 роках будівництво 3 фруктосховищ загальною потужністю 5,1 тис. т. (Піщанський, Тульчинський, Ямпільський райони) та 2 овочесховища потужністю 4,5 тис. т. (Липовецький та Літинський райони) [4].

Виробництво консервів у Вінницькій області з використанням овочів та фруктів, ягід можна побачити у табл. 4.

Таблиия 4.

Виробництво овочевих і фруктових консервів у Вінницькій області за 2012-2018 рр.,тон

\begin{tabular}{|c|c|c|c|c|c|c|}
\hline \multirow[b]{2}{*}{ Роки } & \multicolumn{6}{|c|}{ Різновид продукції } \\
\hline & $\begin{array}{c}\text { Овочі консервовані } \\
\text { натуральні }\end{array}$ & $\begin{array}{c}\%, \\
32012 \text { по } \\
2018 \text { pp. }\end{array}$ & $\begin{array}{c}\text { Джеми, желе, } \\
\text { фруктові } \\
\text { пюре, }\end{array}$ & $\begin{array}{c}\% \\
32012 \text { по } \\
2018 \text { pp. }\end{array}$ & $\begin{array}{c}\text { Соки } \\
\text { фруктові та } \\
\text { овочеві } \\
\text { нектари }\end{array}$ & $\begin{array}{c}\%, \\
32012 \text { по } 2018 \\
\text { рp. }\end{array}$ \\
\hline 2012 & 2911 & $-56,23$ & 31977 & $-32,32$ & 33973 & 18,20 \\
\hline 2013 & 918 & 38,78 & 31148 & $-30,52$ & 65379 & $-38,58$ \\
\hline 2014 & 1896 & $-32,81$ & 29655 & $-27,02$ & 66564 & $-39,67$ \\
\hline 2015 & 1532 & $-16,84$ & 22753 & $-4,88$ & 56318 & $-28,70$ \\
\hline 2016 & 1056 & 20,64 & 20327 & 6,47 & 32985 & 21,74 \\
\hline 2017 & 1274 & $-43,7$ & 21642 & 8,2 & 40156 & 8,4 \\
\hline 2018 & 1356 & $-46,5$ & 22482 & 0,42 & 40254 & 8,4 \\
\hline
\end{tabular}

Джерело: за даними Головного управління статистики у Вінницькій області 


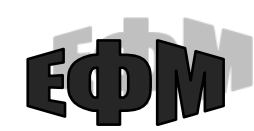

http://efm.vsau.org/

Незважаючи на збільшення обсягів вирощування овочів та плодово-ягідної продукції, спостерігаємо спад обсягів виробництва такої продукції на підприємствах Вінницької області. Відсутність державної підтримки, неплатоспроможність населення, використання ручної праці $\epsilon$ одним із основних стримуючих факторів, які мають негативний вплив на вирощування продукції.

Серед переробних підприємств Вінницької області лідерами, звичайно, є такі підприємства, як ПрАТ «Вінницька харчосмакова фабрика», ПрАТ «Вінницький завод фруктових концентратів і вин», ПрАТ «Могилів-Подільський консервний завод». Саме вони $є$ провідними підприємствами переробки плодів та овочів, які функціонують на ринку протягом тривалого часу.

Для оцінки стану підприємств переробного виробництва, які є основними покупцями та споживачами овочів та ягід Вінницької області, в якості об'єктів дослідження обрано підприємства, які мають відмінності за номенклатурою продукції, розмірами виробничих потужності, структурою активів та іншими характеристиками.

Основними видами продукції ПрАТ «Вінницька харчосмакова фабрика» є хрін, спеції та приправи, кетчуп, гірчиця, каші миттєвого приготування, готові сніданки, квас, безалкогольні напої, мінеральна вода. Реалізовують свою продукцію у місті Вінниці та області, та розроблена маркетингова стратегія виходу на міжнародні ринки збуту.

При здійсненні всіх видів діяльності в кінці 2017 р. ПрАТ «Вінницька харчосмакова фабрика» отримало прибуток в розмірі 7376 тис. грн. Підприємство отримало чистого прибутку майже в два рази більше (118,16\%), це свідчить про джерело поповнення оборотних коштів: 2013 р. 3381 тис. грн, а 2017 р. - 7376 тис. грн.

У 2013 р. сума валового прибутку становила 2093 тис. грн. У 2016 р. сума валового прибутку склала 713 тис. грн. Значення показника свідчить про високий рівень довіри покупців до цієї продукції, а також контроль за якістю та собівартістю продукції.

Фінансовий результат від операційної діяльності збільшився у 2017 р. порівняно з 2013 р.: зі 160 тис. грн у 2013 році до 298 тис. грн у 2017 р., це означає, що підприємство має високу ефективність операційного процесу.

У результаті розглянутих вище факторів підприємство сформувало позитивний чистий фінансовий результат. Порівняно з 2016 р. підприємство отримало чистого фінансового прибутку на 111 тис. грн., що становить 2017 р. - 114 тис. грн., а 2016 р. - 3 тис. грн.

За даними Державного комітету статистики України за 2012-2017 рр., на одну особу припадає в середньому 7 кг на рік консервованих овочів та більше 2 кг фруктів (рис. 1, 2).

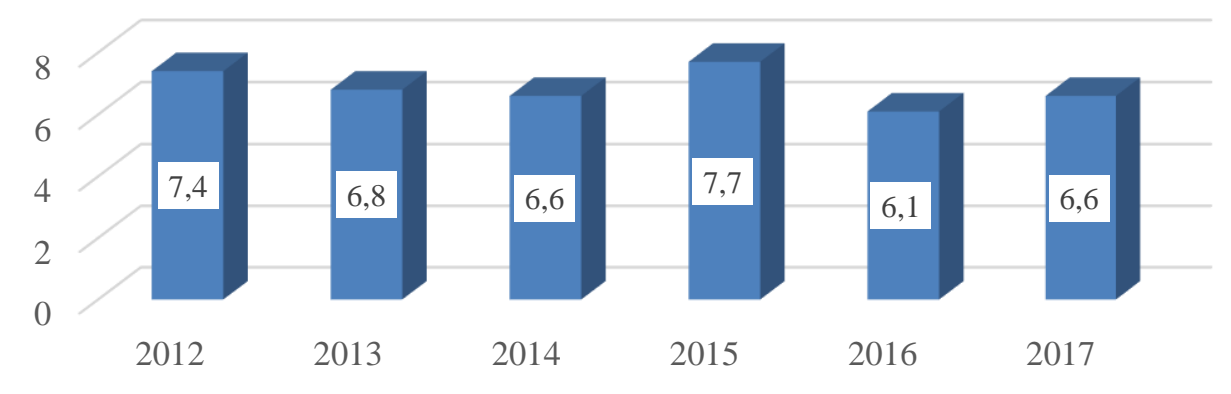

Рис. 1. Споживання овочів консервованих на одну особу в 2012-2017 рр., кГ Джерело: складено за даними Державної служби статистики України [6]

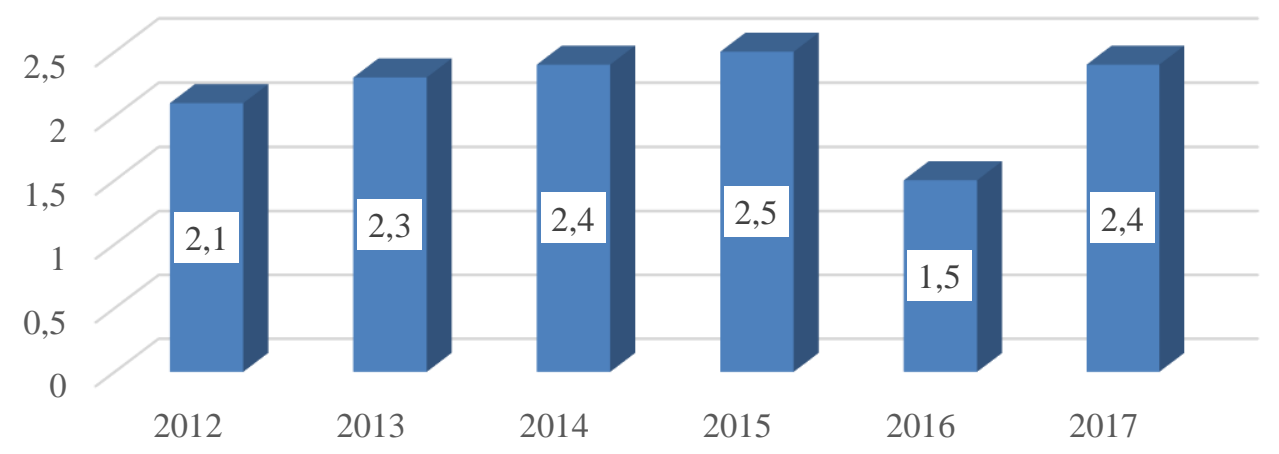

Рис 2. Споживання фруктів консервованих на одну особу у 2012-2017 рр., кг

Джерело: складено за даними Державної служби статистики України [6]. 
В Україні лідерство переробної плодоовочевої галузі належить таким представникам українських торгових марок, як «ВЕРЕС», «Чумак», «Торчин продукт», «Ніжин», «Руна», «Одеський консервний завод дитячого харчування».

Таблиия 5.

Виробництво основних видів плодово-овочевої продукції в переробній промисловості України

\begin{tabular}{|l|c|c|c|c|c|c|c|}
\hline \multicolumn{1}{|c|}{ Продукція } & $\mathbf{2 0 1 3}$ & $\mathbf{2 0 1 4}$ & $\mathbf{2 0 1 5}$ & $\mathbf{2 0 1 6}$ & $\mathbf{2 0 1 7}$ & \multicolumn{2}{|c|}{$\mathbf{2 0 1 7}$ р. \% до } \\
\cline { 5 - 9 } & 118 & 144 & 145 & 143 & 153 & 29,7 & 7,00 \\
\hline $\begin{array}{l}\text { Овочі консервовані } \\
\text { натуральні }\end{array}$ & 669,5 & 571,7 & 386,4 & 366,4 & 375,1 & $-43,97$ & 2,37 \\
\hline Соки фруктові та овочеві & 65,6 & 58,2 & 46,1 & 49,8 & 44,4 & $-32,32$ & $-10,84$ \\
\hline $\begin{array}{l}\text { Джеми, желе фруктові, } \\
\text { пюре та пасти фруктові }\end{array}$ &
\end{tabular}

* Джерело: складено за даними Держсавної служби статистики Украӥни

У 2017 р. виробництво овочевих консервів збільшилось порівняно з 2013 р. майже на 30\%, виробництво джемів, желе та пюре зменшилось на 43,97\%. Виробництво соків має теж не зовсім позитивний характер: спостерігаємо скорочення майже на 32\% порівняно 32013 р.

Така динаміка значною мірою може бути пов'язана з імпортом консервованих продуктів у той період.

Таблиия 6.

Типові товари, що поставляються до країн СС

\begin{tabular}{|l|c|c|c|}
\hline \multicolumn{1}{|c|}{ Найменування товару } & $\begin{array}{c}\text { Поставки 3 } \\
\text { України, млн. євро }\end{array}$ & $\begin{array}{c}\text { Поставки 3 } \\
\text { України, тис. т. }\end{array}$ & $\begin{array}{c}\text { Загальна кількість } \\
\text { поставок до ЄС, тис. т }\end{array}$ \\
\hline Квасоля сушена & 4,0 & 7,1 & 421,1 \\
\hline Гриби свіжі & 3,8 & 0,6 & 18,9 \\
\hline Помідори свіжі & 3,3 & 4,3 & 524,6 \\
\hline Огірки та корнішони свіжі & 2,7 & 2,3 & 64,5 \\
\hline Овочі морожені & 3,1 & 1,9 & 202,9 \\
\cline { 2 - 4 } Джерело: адаптовано автором на основі [10]
\end{tabular}

За даними Укрінформ, імпорт ягід країнами Свропейського Союзу збільшився у 3 рази за останні п'ять років і продовжує зростати. Значні обсяги ягід вирощуються у країнах ЄС, проте попит на цю продукцію залишається суттєво вищим, ніж власне виробництво.

Профільна асоціація «Український клуб аграрного бізнесу» повідомляє, що експорт ягід, фруктів та горіхів до країн ЄС з України у підготовленому вигляді стрімко зріс до 39,4 тис. т у 2016 році. Поставки за перше півріччя 2017 року становили 16,7 тис. т, що в 1,8 разів вище, ніж аналогічний показник 2016 року і в 3,5 рази більший, ніж у 2013 році (4,7 тис. т.).

За сім місяців 2017 року найбільше з України до ЄС експортували суниці та полуниці підготовленої - 34,2\% на 3,150 млн дол. США, малини, ожини, шовковиці, смородини - 65,8\% на 6 млн дол. США.

За останні роки українські підприємства наростили експорт полуниці в ЄС з 442 тис. дол. США у 2013 році до 1,3 млн. дол. США у минулому році. За перше півріччя 2017 року обсяг полуниці у грошовому виразі склав 1,45 млн дол. США і за рік може перевищити 2 млн дол. США.

Вартість експорту ожини, малини, смородини, бузини, порічок теж стрімко зросла з 1,2 млн дол. США у 2013 році до 14,5 млн дол. США минулого року. Темпи зростання залишаються такими ж стрімкими й цього року. За перше півріччя 2017 року експорт цих видів ягід становив 5,4 млн дол. США, що у 2,16 рази перевищує показники аналогічного періоду 2016 року (2,5 млн дол. США). Ці показники перевищують п'ятирічні у 10 разів (533 тис. дол. США).

Висновки. Вінниччина є одним 3 регіонів, що характеризується виключно сприятливими природними та економічними умовами для ефективного розвитку садівництва, здатного постачати конкурентоспроможну плодоовочеву продукцію не лише на внутрішній, а й на міжнародний ринок. Головними напрямами розвитку промислового виробництва плодів і ягід $\epsilon$ поліпшення використання наявних ресурсів господарств і кліматичного потенціалу регіону, завдяки впровадженню інтенсивних ресурсозберігаючих технологій вирощування плодоягідних культур, розширенню мережі підприємств спеціалізованих на виробництві плодів та ягід, удосконаленню розміщення садів, поліпшенню структури їх породного та сортового складу, створення інтегрованих виробничо-господарських структур з виробництва, зберігання, промислової переробки та реалізації садівницької продукції тощо. Основним чинником підвищення ефективності виробництва плодоовочевої продукції у регіоні має стати зміцнення матеріально-технічної бази підприємств, зниження ціни на продукцію за рахунок державного регулювання такої продукції, зниження імпорту плодів та овочів, добре налагоджені маркетингові стратегії збуту, організація реклами. 


\section{Список використаних джерел}

1. Азізов С.П., Саблук П.Т., Канінський П.К. Організація аграрного виробництва і бізнесу: підручник для студентів ВНЗ. Київ, 2006. 788 с.

2. Вінницька обласна державна адміністрація. URL: http://www.vin.gov.ua.

3. Державна служба статистики України. URL: http://www.ukrstat.gov.ua /druk/soc_ek /2004/publ042004.htm.

4. Інвестиційний портал Вінниччини. URL: http://www.vininvest.gov.ua//.

5. Концепція розвитку овочівництва та переробної галузі: Розпорядження Кабінету Міністрів України від 31.10.2011 p. №1120-p. URL: http://zakon2.rada.gov.ua/laws/show/1120-2011-p.

6. Косовець Г.М. Можливості адаптації зарубіжного досвіду державного регулювання виробництва овочевої продукції до умов вітчизняного ринку. Ефективна економіка. 2013. №7. URL: http://www.ekonomy.nayka.com.ua./.

7. Статистичний збірник України в цифрах. Державний комітет статистики України. 2012. URL: https://ukrstat.org/uk/druk/publicat/Arhiv_u/01/Arch_Ukr_htm.

8. Статистичний збірник України в цифрах / Державний комітет статистики України. 2017. URL: https://ukrstat.org/uk/druk/publicat/kat_u/publ1_u.htm.

9. Шевчук Г.В. Фактори, що впливають на ефективність організаційно-економічного механізму удосконалення плодоовочевої галузі. Аналітичний центр Нова економіка. Київ, 2016. С. 58-60.

10. URL: http://ec.europa.eu/eurostat/web/agriculture/data/main-tables.

11. URL: https://www.ukrinform.ua /rubric-society/2364021- u- zdorovomu- tili- ukraincam- predstavilirekomendacii -dla-harcuvanna.html.

12. URL: https://day.kyiv.ua/uk/article/ekonomika/racion-bidnosti.

13. URL: https://moz.gov.ua/.

References
1. Azizov S.P., Sabluk P.T., Kaninskuy P.K., (2006). Organizaci'a agrarnogo vurobnutsa i bisnesy. Pidrychnic. Kiev. 788p. [In Ukrainian].

2. Vinnitska obl'asna dergavna administracia. URL: http://www.vin.gov.ua.

3. Derzavna sl'uzba statustuk'u Ukraine URL: http://www.ukrstat.gov.ua /druk/soc_ek /2004/publ042004.htm.

4. Investuciynu'y portal Vinnytsia URL: http://www.vininvest.gov.ua/.

5. Concepcia rozvutky ovocivnutstva ta pererobku galuzi / URL: http://zakon2.rada.gov.ua/laws/show/1120-2011-p.

6. Kosovec' G.M. (2013). Mozluvosti adaptaciy zarybiznogo dosvidy derzavnogo regyluvanya vurobnutstva ovozevoi prodykcii do umov vitzuzn'anogo runky. Efektuvna economy. №7. [In Ukrainian].

7. Statustuchnuy zbirnuk Ukrainu v c'ufrax URL: https://ukrstat.org/uk/druk/ publicat/Arhiv_u /01/Arch_Ukr_.htm.

8. Statustuchnuy zbirnuk Ukrainu v c'ufrax URL: https://ukrstat.org/uk/druk/ publicat/ kat_u/publ1_u.htm

9. Shevcuk G.V. (2016). Factory cto vpluvayt' na efectuvnist' organizaziyno economichnogo mehanizmy udockonalenya plodoovocevi galyzi. Analituchnuy centr. Kiev. [In Ukrainian].

10. Eurostat.URL: http://ec.europa.eu/eurostat/web/agriculture/data/main-tables.

11. URL: https:// www.ukrinform.ua/rubric-society/2364021-u-zdorovomu- tili- ukraincam- predstavilirekomendacii-dla-harcuvanna.

12. URL: https://day.kyiv.ua/uk/article/ekonomika/racion-bidnosti.

13. URL: https://moz.gov.ua/.

\section{Інформація про автора}

САМБОРСЬКА Оксана Юріївна - кандидат економічних наук, доцент кафедри адміністративного менеджменту та альтернативних джерел енергії, Вінницький національний аграрний університет (21000, м. Вінниця, вул. Пирогова, 3, e-mail: super_oksana30@ukr.net).

SAMBORSKA Oksana - Candidate of Economic Sciences, Associate Professor of the Administrative Management and Alternative Energy Sources Department, Vinnytsia National Agrarian University (21000, Vinnytsia, 3, Pirogov Str., e-mail: super_oksana30@ukr.net).

САМБОРСКАЯ Оксана Юрьевна - кандидат экономических наук, доцент кафедры административного менеджмента и альтернативных источников энергии, Винницкий национальный аграрный университет (21000, г. Винница, ул. Пирогова, 3, e-mail: super_oksana30@ukr.net). 